\title{
Study of Performance Test of Ruston Diesel Engine Using Rapeseed Oil
}

\author{
Vishal Garg ${ }^{1}$ Neelesh Khandare ${ }^{2}$ Gautam Yadav ${ }^{3}$ \\ M.E.-Tribology \& Maintenance Engineering, SGSITS INDORE (M.P.) India
}

\begin{abstract}
In this paper Study of Performance Test of Ruston Diesel Engine Using Rapeseed Oil. They free the user from rising energy costs, can be used anywhere, produce no pollution and provide healthy exercise. Basically Ruston engine was build for Marin and navy ships. Energy is the primary and most universal measure of all kind of work by human Being and nature. Everything what happen in the world in the expression of flow of energy is one of its form. Most people use the world energy for input to their bodies or to the machines and thus about fuels and power. Energy is an important input in all sectors of counters economy.
\end{abstract}

\section{INTRODUCTION}

The liquid biofuels most widely used for transport today are ethanol and biodiesel, which can both be used in existing vehicles where ethanol with gasoline and biodiesel is blinded with conventional diesel fuel. There is a growing interest in rapeseed oil as fuel because of the similarity in its property when compound to those of diesel fuels diesel engines operated on rapeseed oil have lower emission on carbon mono oxide, unburned hydro carbon, carbon mono oxide, particular matter and air toxics that when operated on petroleum based diesel fuel Emission of pollutant comparable with that of diesel oil. Criteria pollutant are reduced with rapeseed oil used.[1]

\section{MODIFICATION OF RUSTON ENGINE:-}

Generally in Diesel Engine, one fuel tank system is provided. But we are using Rapeseed oil as a fuel which is comparatively thicker to Diesel. Hence instead of using one fuel tank system, use of two fuel tanks is advisable one for regular diesel supply and other for Rapeseed oil. As soon as we start our engine with regular fuel it warms up. The heat is used to thin the Rapeseed oil. After a few minutes or so, we use a dashboard control to switch over a vegetable oil tank. Dual tank system also means that a vehicle can, if necessary refuel at a regular fuel station.[2]

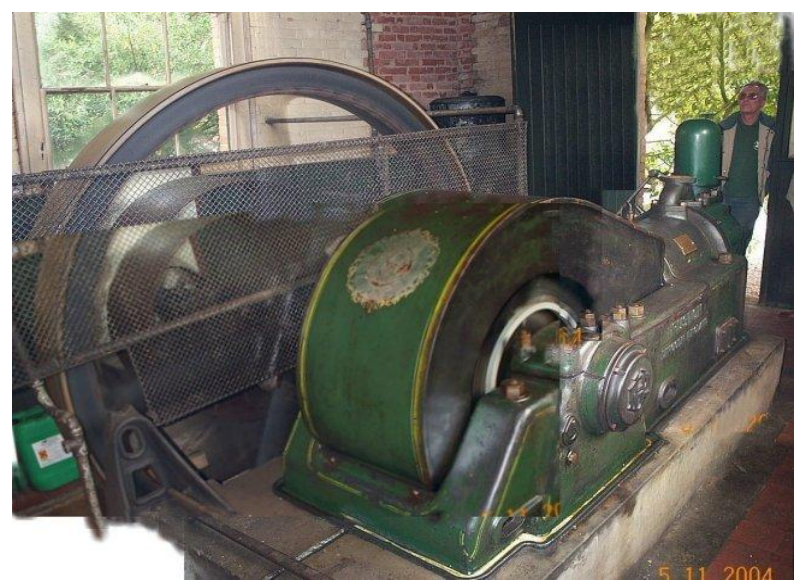

III. CHEMICAL ANALYSIS :-

Chemical analysis performed on the oil sample to calculate different properties which are as follows:-

- Phosphorous content

- Ash content

- Flash point

- Water content

- Kinematic Viscosity

- Iodine Value 
Different reagents and apparatus are used to calculate certain values so as to compare the obtained values of following properties with the value of diesel as prescribed according to Germen Quality Standard.

\subsection{Phosphorous Content:-}

Organic matter in the sample of $10 \mathrm{ml}$ is decomposed by ignition in the presence of zinc oxide. The absorption of Molybdenum blue complex is proportional to the phosphorous concentration in the sample and is read at approximately $820 \mathrm{~mm}$ in a $5 \mathrm{~cm}$ cell.

\subsection{Ash Content:-}

This is measured by burning the sample until only as and carbon remain. The residue is ash in a muffle furnace at 775 degree centigrade and then weighed.

\subsection{Flash Point:-}

Flash point is measured by Pensky-Martens apparatus. An oil sample is heated slowly and exposed to a flame at fixed temperature intervals. The flash point is the lowest temperature at which the flame causes the sample to burn.

\subsection{Kinematic Viscosity:-}

Viscosity is measured with a U-tube viscometer. The viscometer has a defined capillary through which the oil flows. The tube is then pressed or sucked up to full the higher storage bulb in the right leg. This bulb has graduation marks ablove and below and from the time needed for the oil to flow under gravity from the upper market to lower the kinematic viscosity can be catculated. A thermostatically controlled water bath is required to maintain the oil at 40 degree centigrade for the duration of the test.

\subsection{Iodine Value:-}

Transfer $25 \mathrm{ml}$ of cc14 and $25 \mathrm{ml}$ of wij's solution each of two- $500 \mathrm{ml}$ iodine titration flasks. Strain the oil sample through a filter paper to remove all the solid material and moisture present in the sample. Accurately weigh $0.05-0.5 \mathrm{gm}$ of the sample and transfer to one of the two flask. Close the flasks with glass stoppers moistened with a little $10 \% \mathrm{KI}$ solution. Swirl the flasks to mix the contents intimately and keep in dark for about 30 degree centigrade. Add $20 \mathrm{ml}$ of KI solution to both the flask, washing down the stopper, and dilute with about $100 \mathrm{ml}$ of distilled water. Titrate the liberated iodine with N/10 Na2S203 solution. When the color of the solution turns light yellow add about $1 \mathrm{ml}$ of freshly prepared starch solution and continue the titration as A $\mathrm{ml}$ and that in blank titration as B $\mathrm{ml} .[3]$

\subsection{Water Content:-}

A weighed portion of oil is injected into the titration vessel of a Karl Fischer Titrator. When all the water has been titrated, excess iodine is detected by an electrometric end point detector and the titration is terminated. [4]

\section{OBSERVATIONS:-}

For pure diesel oil

\begin{tabular}{|l|l|l|l|l|l|l|l|}
\hline S.NO. & $\begin{array}{l}\text { SPEED } \\
\text { IN RPM }\end{array}$ & $\begin{array}{l}\text { LOAD } \\
\text { IN KG }\end{array}$ & $\begin{array}{l}\text { SPRING } \\
\text { BALAN } \\
\text { CE }\end{array}$ & $\begin{array}{l}\text { FUEL } \\
\text { CONSU } \\
\text { MPTION } \\
\text { IN CC }\end{array}$ & $\begin{array}{l}\text { TIME IN } \\
\text { SECON } \\
\text { D }\end{array}$ & $\begin{array}{l}\text { BRAKE } \\
\text { POWER } \\
\text { IN KW }\end{array}$ & $\begin{array}{l}\text { MASS } \\
\text { FUEL } \\
\text { SEC. }\end{array}$ \\
\hline $\mathbf{1}$ & 400 & 100 & 22 & 20 & 88 & 16.336 & 0.227 \\
\hline $\mathbf{2}$ & 400 & 80 & 20 & 20 & 79.5 & 12.566 & 0.251 \\
\hline $\mathbf{3}$ & 400 & 60 & 15 & 20 & 76 & 9.424 & 0.263 \\
\hline $\mathbf{4}$ & 400 & 40 & 12 & 20 & 60 & 5.864 & 0.333 \\
\hline
\end{tabular}

\section{For $80 \%$ mixture of Rapeseed oil with $20 \%$ Diesel}

\begin{tabular}{l|l|l|l|l|l|l|l|} 
S.NO & $\begin{array}{l}\text { SPEED } \\
\text { IN RPM }\end{array}$ & $\begin{array}{l}\text { LOAD } \\
\text { IN KG }\end{array}$ & $\begin{array}{l}\text { SPRING } \\
\text { BALAN } \\
\text { CE }\end{array}$ & $\begin{array}{l}\text { FUEL } \\
\text { CONSU } \\
\text { MPTION } \\
\text { IN CC }\end{array}$ & $\begin{array}{l}\text { TIME IN } \\
\text { SECON }\end{array}$ & $\begin{array}{l}\text { BRAKE } \\
\text { POWER } \\
\text { IN KW }\end{array}$ & $\begin{array}{l}\text { MASS } \\
\text { OF } \\
\text { FUEL } \\
\text { SEC. }\end{array}$ \\
\hline $\mathbf{1}$ & 400 & 100 & 23 & 20 & 71 & 16.126 & 0.281 \\
\hline $\mathbf{2}$ & 400 & 80 & 18 & 20 & 65 & 12.566 & 0.307 \\
\hline $\mathbf{3}$ & 400 & 60 & 15 & 20 & 59 & 9.424 & 0.338 \\
\hline $\mathbf{4}$ & 400 & 40 & 12 & 20 & 54 & 5.864 & 0.37 \\
\hline
\end{tabular}




\section{For Pure Rapeseed Oil}

\begin{tabular}{|l|l|l|l|l|l|l|l|} 
S.NO & SPEED & LOAD & SPRING & FUEL & TIME IN & BRAKE & MASS \\
IN RPM & IN KG & $\begin{array}{l}\text { BALAN } \\
\text { CENSU }\end{array}$ & $\begin{array}{l}\text { SECON } \\
\text { MPTION } \\
\text { DOWER }\end{array}$ & $\begin{array}{l}\text { POF } \\
\text { IN KW }\end{array}$ & $\begin{array}{l}\text { FUEL } \\
\text { SEC. }\end{array}$ \\
\hline $\mathbf{1}$ & 400 & 100 & 22 & 20 & 71 & 16.126 & 0.281 \\
\hline $\mathbf{2}$ & 400 & 80 & 20 & 20 & 65 & 12.985 & 0.307 \\
\hline $\mathbf{3}$ & 400 & 60 & 15 & 20 & 59 & 9.424 & 0.338 \\
\hline $\mathbf{4}$ & 400 & 40 & 12 & 20 & 54 & 5.864 & 0.37 \\
\hline
\end{tabular}

\section{CALCULATION}

For calculation of brake power following formula

Brake Power -

Where $\mathrm{W}=$ Load in $\mathrm{Kg}$

$$
B P=(W-S) \pi \mathrm{DN} / 60
$$

$\mathrm{S}=$ spring Balance

$\mathrm{D}=$ Diameter $($ in $\mathrm{mm})$

$\mathrm{N}=\operatorname{speed}($ in $\mathrm{rpm}$ )

For Pure Diesel oil

$16.336,12.566,9.424,5.864(\mathrm{KW})$

For $80 \%$ mixture of Rapeseed oil with $20 \%$ Diesel

$16.126,12.775,9.424,5.654(\mathrm{KW})$

For rapeseed oil

$16.545,12.566,9.215,5.654(\mathrm{KW})$

\section{SMOKE ANALYSIS:-}

The necessity of smoke analysis is to calculate the value of carbon monoxide, Hydrocarbon, Carbon-dioxide, and other particulate. So as to check whether the fuel ie...., Rapeseed oil which we are using is ecofriendly or not. The smoke analysis test is performed with the help of a apparatus namely smoke analyzer. The apparatus consists of three filters through which the smoke which is released from the vehicle enters to the filter and then pass to the reaming filters. [5]

\section{CONCLUSION:-}

Based on the extensive literature about exhaust gas emission resulting from the combustion of rapeseed oil. Data were compiled and differentiated according to the underlying engine test procedure, fuel and design. In the light of the known effect of individual exhaust gas compressed to diesel fuel. In order to utilize the rapeseed oil in regions with high NOx concentration, it is necessary to determine the expected ozone formation in low attitudes and to compare this with that of diesel fuel.

Also the color of smoke produced by engine running on diesel produced black color whereas the engine running on rapeseed produced white color smoke. It shows that the values of carbon monoxide and hydrocarbon particulates is less as compressed to diesel.

\section{REFERENCES}

[1] Biofuel for transport: global potential and amplifications for energy and agriculture. Worldwatch Institute, London, Earthscan, 2007

[2] Elsbett Diesel Technology- ELSBETT ENGINE available at: http://www.elsbett.com/gb/elsbett-dieseltechnology/elsbett engine.html .

[3] Vertix - Das new pflanzenol 1- tanksystem von LINTEC available at : http://www.rapsol.de/26.html .

[4] Greenbull 1-tank/2-tanksystem available at: http://www.greenbull.at/index.php

[5] ELSBETT conversion technology- fundamentals available at: http://www.elsbett.com/gb/elsbettconversiontechnology-fundamentals.html 